УДК 338.432:633.85(474.53)

(C) 2014

Сщенко I. B., аспірант

(науковий керівник - кандидат економічних наук, професор В. I. Аранчій)

Полтавська державна аграрна академія

\title{
СТАН І ПРОБЛЕМИ ВИРОБНИЦТВА ОЛІЙНИХ КУЛЬТУР У ПОЛТАВСЫКІЙ ОБЛАСТІ
}

\section{Рецензент - кандидат економічних наук О. В. Безкровний}

Досить стрімкий розвиток олійної галузі та зростання попиту на жири рослинного походження у світі зумовили суттєве підвищення інтересу науковиів до проблем виробництва олійних культур в Україні. У статті розглянуто основні тендениії розвитку даної галузі, зовнішні та внутрішні чинники, щуо здійснюють вплив на неї, визначено організачійноекономічні особливості формування ефективного розвитку галузі виробництва олійних культур, здійснено аналіз економічної ефективності виробництва олійних культур, а також визначено головні резерви ї̈ підвищчення у Полтавській області.

Ключові слова: економічна ефективність, олійні культури, посівна площа, валовий збір, рентабельність виробництва.

Постановка проблеми. Зростання попиту на жири рослинного походження протягом 90-х років минулого століття призвело до зміни у розподілі посівних площ аграрного сектора України. Значну частку в структурі посівних площ зайняли олійні культури, найпопулярнішою серед яких став соняшник.

За останні 20 років площі під соняшником зросли з 1,6 млн га до 4,1-4,5 млн га. Розширюються посівні площі й інших олійних культур таких як ріпак та соя. Так, за аналогічний період посівні площі ріпаку збільшилися у 12 разів, а валовий збір - у 14,4 разу; сої - у 7 та 11 разів відповідно.

Загалом, вітчизняна галузь виробництва олійних культур протягом 20 років демонструє зростання та розширення. Свідченням цього є збільшення посівних площ і валових зборів основних олійних культур України. Проте, зростання це відбувалося екстенсивним шляхом, а рівень урожайності майже не змінився з 1990 року.

Аграрний сектор економіки України потребує підвищення ефективності виробництва олійних культур, що можливо за умови вдосконалення технологій, підвищення рівня матеріальнотехнічної бази, чіткого дотримання агротехнічних вимог. Це стосується і галузі виробництва олійних культур.
Аналіз останніх досліджень і публікацій, у яких започатковано розв'язання проблеми. Питанням, що пов'язані з виробництвом олійних культур, приділяється значна увага у працях науковців. Так, О. С. Сало відмічає важливість моніторингу регіональних ринків олійних культур, під впливом яких формується вітчизняна олійна галузь. Автор загострює увагу на необхідності покращання технологічного забезпечення галузі (засоби захисту рослин, добрива, елітне насіння). Зменшення витрат на технологічне забезпечення, на його думку, призводить до зниження урожайності [9]. Питаннями виробництва основних олійних культур займаються також Н. В. Потриваєва, І.В.Чехова, І. О. Кислицька, Т. 3. Таранюк, які в основу своїх досліджень покладають проблеми підвищення економічної ефективності виробництва основних олійних культур та визначення факторів розвитку олієжирового комплексу в цілому $[7,12]$.

Значна кількість наукових праць присвячена особливостям виробництва окремих олійних культур. Так, питаннями економічної ефективності виробництва й реалізації соняшнику займаються В. П. Федоряка, Т. І. Олійник, О. Маслак та інші $[4,5,11]$. Проблемами ефективного виробництва ріпаку й функціонування ріпакового комплексу займаються такі вчені, як А. В. Дубель, А. В. Фаїзов [3, 10]. Питаннями виробництва сої займається Білоусов О. М., який у своїх працях розглядає сою як одну із основних культур сільськогосподарського виробництва, а Е. В. Репілевський, аналізуючи сучасний стан виробництва сої, підкреслює необхідність формування в Україні соєвого поясу у зоні лісостепу $[1,8]$.

Проте в літературних джерелах недостатньо дослідженими залишаються питання вирішення проблем, що пов'язані із виробництвом олійних культур на рівні регіону та держави в цілому. Крім того, більшість учених у своїх працях концентрують увагу на окремих олійних культурах, не розглядаючи дане питання комплексно, з урахуван- 


\section{СТОРІНКА МОЛОДОГО ВЧЕНОГО}

ням зовнішніх і внутрішніх чинників. Наукові дослідження 3 даного напрямку зосереджуються переважно на вирішенні окремих актуальних завдань, не надаючи системних рекомендацій.

Мета і завдання дослідження. Мета дослідження полягає у виявленні найважливіших чинників, що впливають на ефективність виробництва та реалізації олійних культур; визначенні особливостей розвитку даної галузі в розрізі Полтавської області; вивченні основних проблем виробництва олійних культур та шляхів їх вирішення.

Для досягнення поставленої мети було виділено такі завдання:

- визначити організаційно-економічні особливості формування ефективного розвитку галузі виробництва олійних культур;

- 3'ясувати основні зовнішні та внутрішні чинники, що здійснюють вплив на розвиток досліджуваної галузі;

- визначити резерви підвищення ефективності виробництва олійних культур для досліджуваного регіону.

Результати дослідження. Управління агропромисловим комплексом та забезпечення його продуктивності й ефективності здійснюється через нарощування конкурентоспроможної продукції, що користується попитом на внутрішньому й зовнішньому ринках. Аби досягти вагомих результатів та підвищити рівень розвитку агропромислового комплексу в цілому, необхідною $є$ побудова ефективного організаційно-економічного механізму функціонування кожної галузі.
Аналіз свідчить, що за останні два десятиліття виробництво олійних культур в Україні зросло більше, ніж учетверо, а в Полтавській області - у 3,8 разу, у той час, як виробництво зернових та зернобобових культур в Україні у 2012 р. порівняно 31990 р. зменшилося на 9,5\%, а в Полтавській області - на 14,3\%. Темп приросту обсягів виробництва олійних культур у 1990-2012 pp. здебільшого випереджає даний показник по зернових та зернобобових культурах (рис. 1). Аналіз даних рисунку 1 свідчить, що виробництво олійних культур має тенденцію до зростання як в Україні, так і в Полтавській області. Не зважаючи на те, що в 2012 р. темп приросту виробництва олійних культур у досліджуваному регіоні був нижчим, ніж по Україні (80,1 \% - у Полтавській області, 138,1 \% - в Україні), загальна тенденція виробництва олійних культур - зростаюча.

Зважаючи на стале нарощування обсягів виробництва олійних культур, проаналізуємо динаміку їх частки у загальній структурі посівних площ України та Полтавської області (рис. 2).

Як видно 3 даних рисунку 2, питома вага олійних культур у загальній посівній площі України та Полтавської області має тенденцію до зростання. Особливо стрімке збільшення посівних площ під даними культурами спостерігалося у 1995-2010 pр., коли показник частки олійних культур у посівній площі України зріс із 7,1\% у 1995 р. до 24,3 \% у 2010 р. Аналогічна тенденція спостерігалася і в Полтавській області (6,4\% у 1995 р. та $24,5 \%$ - у 2010 р.).

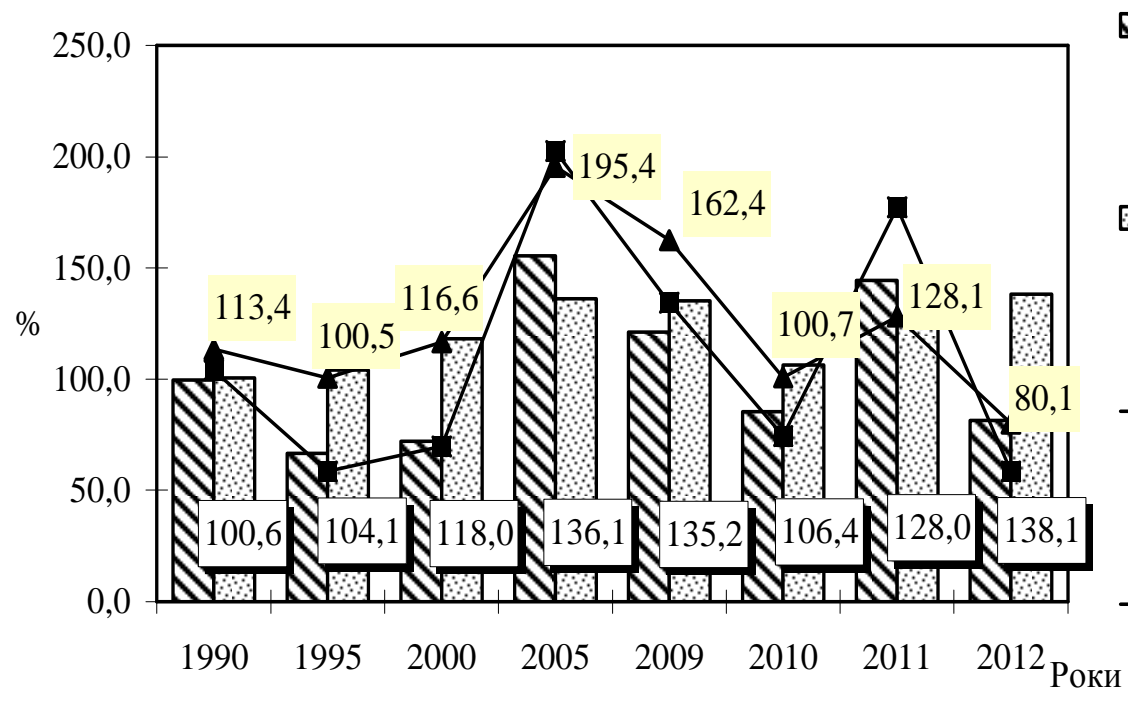

$\mathbf{W}$ Темп приросту виробництва зернових і зернобобових культур в Україні

Темп приросту виробництва олійних культур в Україні

виробництва зернових і зернобобових культур у Полтавській області

Темп приросту виробництва олійних культур у Полтавській області

\section{Рис. 1. Темпи приросту виробництва зернових $і$ зернобобових та олійних культур в Украӥні й Полтавській області у 1990-2012 рр., \%}

Джерело: розраховано автором за даними [6] 


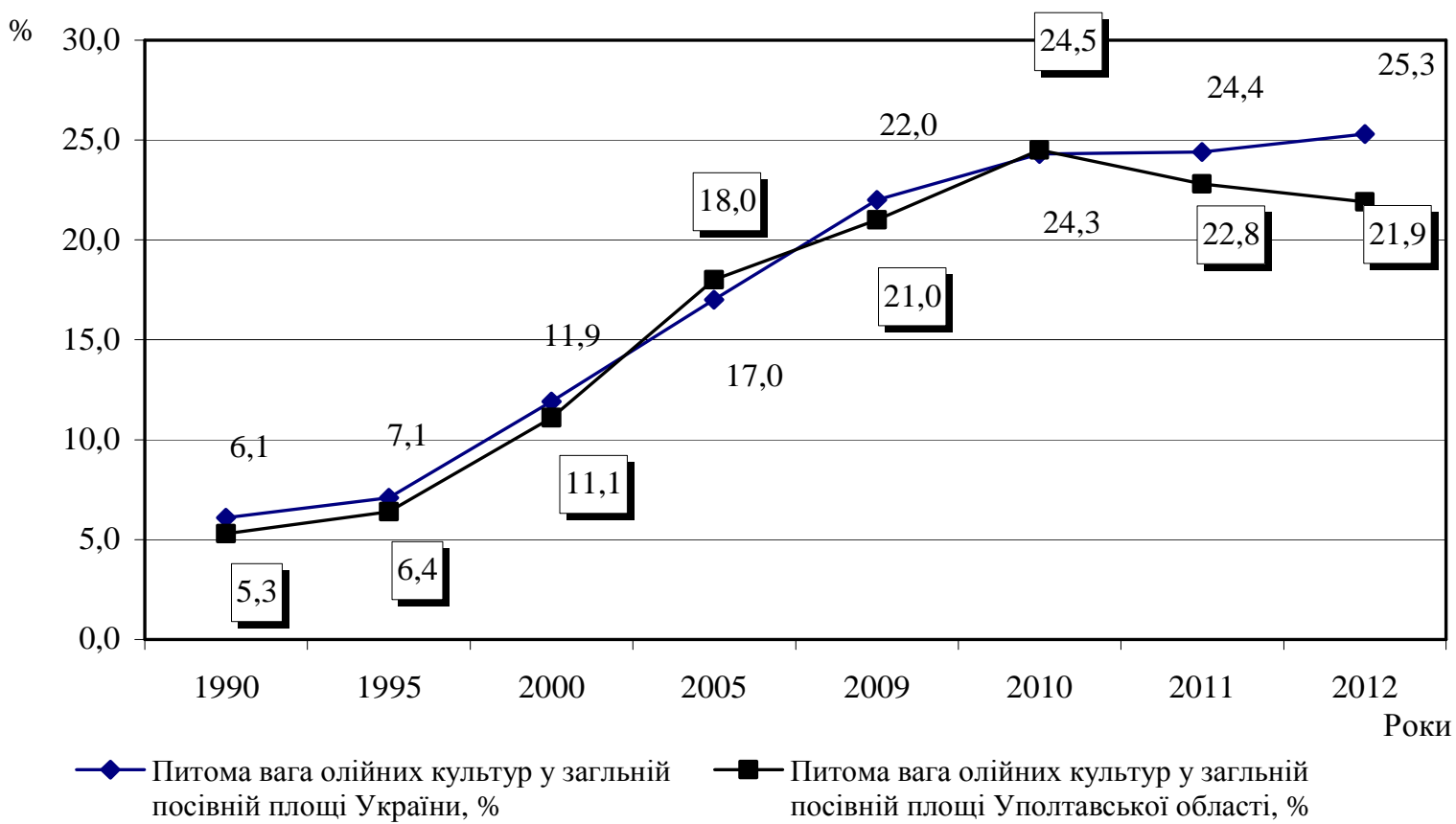

Рис. 2. Питома вага олійних культур у загальних посівних площах України та Полтавської області в 1990-2012 рр., \%

Джерело: розраховано автором за даними [6]

У 2011 р. досліджуваний показник дещо знижується $(24,4 \%$ в Україні та $22,8 \%$ у Полтавській області), а в 2012 р. значення питомої ваги олійних культур в загальній посівній площі України зростає до 25,3\%, у Полтавській області - знижується до $21,9 \%$.

Ефективне функціонування галузі залежить від ресурсного потенціалу виробництва, що включає природні, фінансові, матеріальні, людські, інформаційні, технологічні ресурси, а також від організаційно-економічного механізму, що забезпечує організацію, оптимізацію та контроль за діяльністю галузі в цілому.

Ресурсний потенціал і організаційна складова у поєднанні покликані забезпечити безперебійну й ефективну роботу галузі.

На рисунку 3 визначено складові ефективного функціонування галузі виробництва олійних культур та їх взаємозв' язок $з$ точки зору забезпеченості ресурсами й дієвого організаційноекономічного механізму.

На роботу галузі, безперечно, впливають різного роду фактори, що позначається на кінцевих економічних результатах діяльності, на ефективності, гнучкості, стабільності розвитку підприємств тощо.
Такі фактори, вважаємо, слід класифікувати на зовнішні та внутрішні (рис. 4).

3 огляду на значну кількість факторів, що можуть впливати на розвиток галузі виробництва олійних культур, необхідним $є$ визначення резервів подальшого ii розвитку та підвищення економічної ефективності.

Для підвищення ефективності вирощування олійних культур серед основних напрямів можна виокремити:

- удосконалення регіонального розміщення посівів, виходячи з ботанічних і біологічних особливостей культур, технології вирощування, підбору ефективних засобів захисту;

- дотримання чергування у полях сівозмін;

- застосування інтенсивних технологій вирощування і збирання для зниження витрат на одиницю продукції; впровадження високоврожайних гібридів;

- залучення додаткових матеріальних ресурсів через пошук потенційних інвесторів та кредиторів [2].

У комплексі ці заходи сприятимуть підвищенню ефективності функціонування галузі виробництва олійних культур та забезпечить максимальний економічний ефект діяльності. 


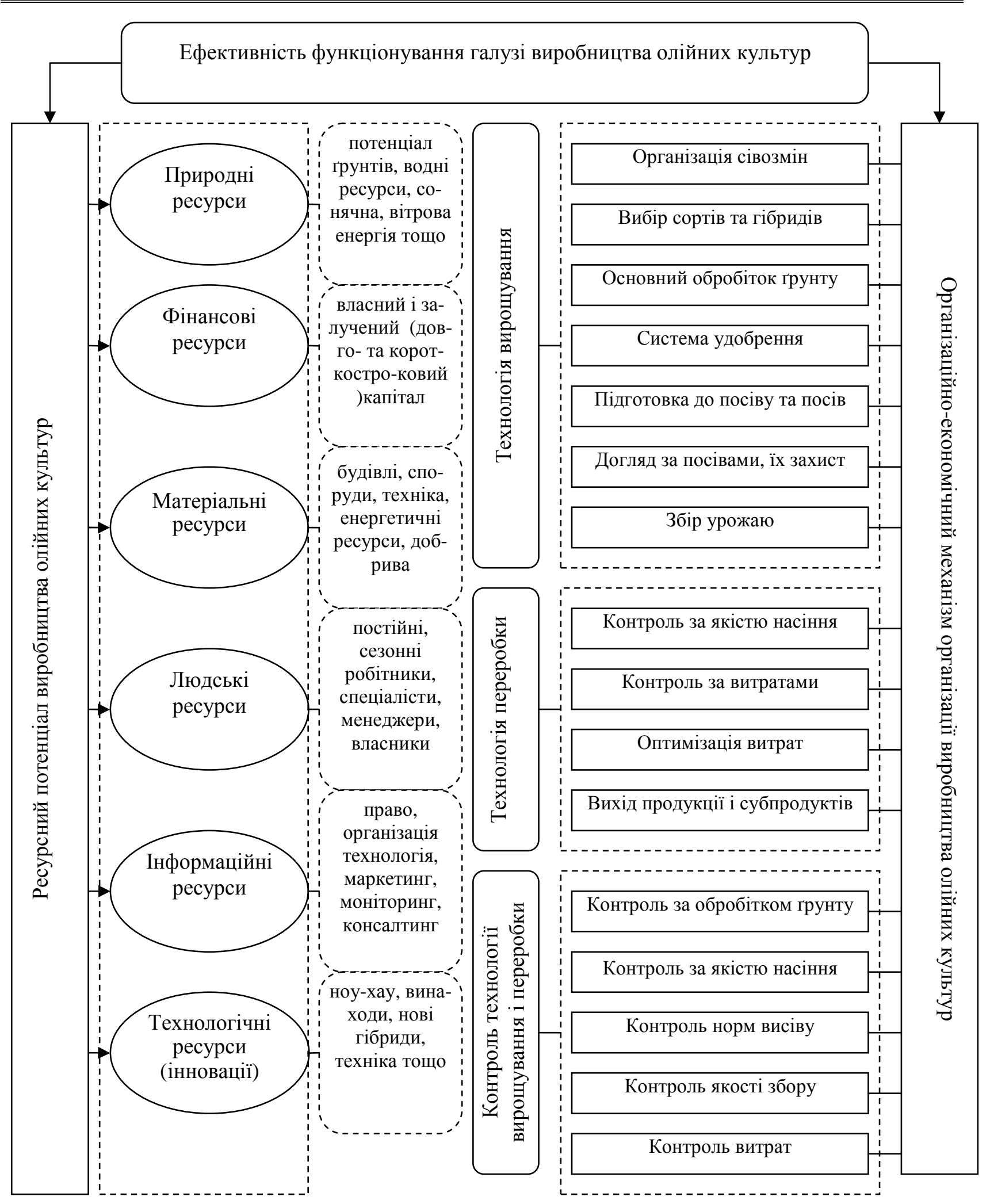

Рис. 3. Складові ефективності функціонування галузі виробництва олійних культур

Джерело: розроблено автором 


\section{СТОРІНКА МОЛОДОГО ВЧЕНОГО}

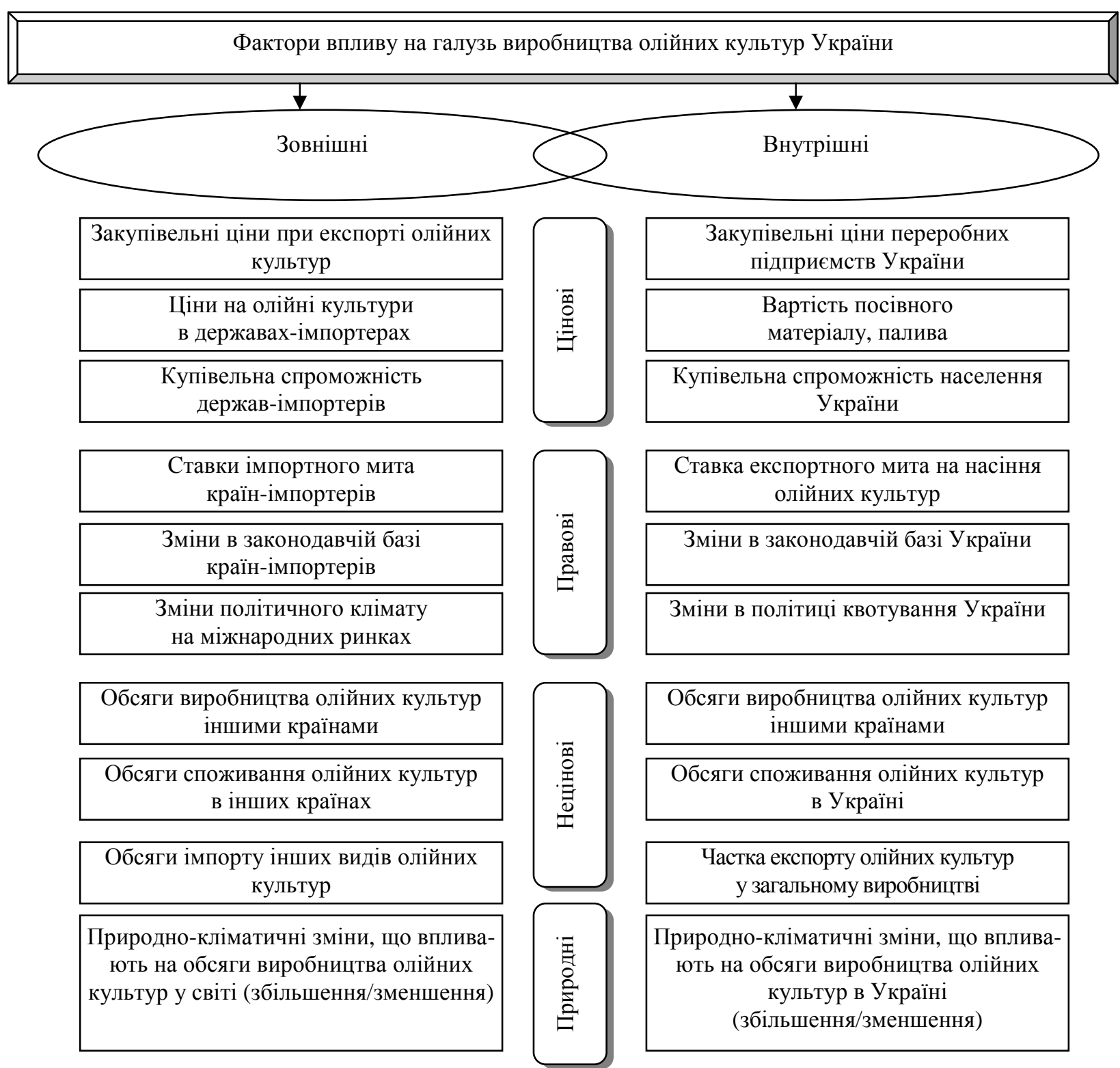

Рис. 4. Фактори впливу на галузь виробництва олійних культур Украӥни

Джерело: розроблено автором

\section{Висновки:}

1. За останні два десятиліття виробництво олійних культур в Україні зросло більше, ніж учетверо, а в Полтавській області - у 3,8 разу.

2. Ефективне функціонування галузі залежить від ресурсного потенціалу виробництва, що включає природні, фінансові, матеріальні, людські, інформаційні, технологічні ресурси, а також від організаційно-економічного механізму, що забезпечує організацію, оптимізацію та конт-

\section{БІБЛІОГРАФІЯ}

1. Білоусов О. М. Формування ринку сої та продукції іiі переробки в Україні [Електронний pecypc]. - режим доступу: www.nbuv.gov.ua роль за діяльністю галузі в цілому. Ресурсний потенціал і організаційна складова у поєднанні покликані забезпечити безперебійну й ефективну роботу галузі.

3. Підвищення ефективності вирощування олійних культур можна досягти як за рахунок інтенсивних, так і за рахунок інтенсивних факторів: дотримання сівозмін, залучення додаткових ресурсів, оптимізація виробничих процесів.

2. Бритвєнко А. С. Напрями розвитку і підвищення економічної ефективності виробництва та переробки соняшнику в регіонах України // 
А. С. Бритвєнко // Вісник Бердянського університету менеджменту і бізнесу. - 2013. - №2. C. $110-113$.

3. Дубель А. В. Особливості та економічна ефективність вирощування ріпаку / А. В. Дубель // Інноваційна економіка. - 2010. - №4. - С. 88-91.

4. Маслак O. Нові олійні рекорди / О. Маслак // Пропозиція. - 2012. - № 6. - С. 36-40.

5. Олійник T. I. Стан та проблеми виробництва соняшнику в Україні. [Електронний ресурс]. режим доступу: www.nbuv.gov.ua

6. Офіційний сайт Державної служби статистики України. [Електронний ресурс]. - режим доступу: http://www.ukrstat.gov.ua.

7. Потриваєва Н. В. Ефективність виробництва і розвитку ринку олійних культур в Україні. [Електронний ресурс]. - режим доступу: www.nbuv.gov.ua.

8. Репілевський Е. В. Економічна ефективність виробництва сої в ринкових умовах господарювання. [Електронний ресурс]. - режим доступу: www.nbuv.gov.ua

9. Сало О.С. Підвищенння ефективності вирощування основних олійних культур / О. С. Фаїзов // Вісник ЦНЗ АПВ Харківської області. - 2010. - Вип. 7. - С. 294-300.

10. Фаїзов А. В. Олієжировий комплекс: проблеми і фактори розвитку [Електронний ресурс]. - режим доступу: www.nbuv.gov.ua.

11. Федоряка В. П. Ефективність виробництва i реалізації соняшнику в Україні / В.П. Федоряка, Л. А. Бахчиванжи, С. В. Почколіна // Вісник соціально-економічних досліджень. - 2010. - №2. C. 139-144.

12. Чехова I. B. Перспективи розвитку ринку основних олійних культур / I. В. Чехова, I. О. Кислицька, Т. 3, Таранюк // Економіка АПК. - 2012. - №6. - C. 43-48. 